PUBLIKAUMA: Jurnal Ilmu Administrasi Publik

Available online http://ojs.uma.ac.id/index.php/publikauma

\title{
Aspek Administrasi dan Politik dalam Kebijakan Pemekaran Kelurahan di Kota Surakarta
}

\section{Administrative and Political Aspects in the Urban Expansion Policy in the City of Surakarta}

\author{
Dimas Ratu Tiemority \& Didik Gunawan Suharto* \\ Program Studi Administrasi Negara, Fakultas Ilmu Sosisal dan Ilmu Politik, Universitas Sebelas \\ Maret, Surakarta, Indonesia
}

Disetujui: Maret 2021; Direview: April 2021;Diterima: Mei 2021

\section{Abstrak}

Penelitian ini bertujuan untuk menganalisis faktor yang mempengaruhi pemekaran wilayah kelurahan di Kelurahan Semanggi Kota Surakarta. Penelitian ini menggunakan jenis penelitian deskriptif kualitatif dengan pendekatan studi lapangan. Data dikumpulkan melalui observasi, dokumentasi, dan wawancara terhadap pemangku kepentingan daerah terkait perumusan kebijakan pemekaran kelurahan. Informan penelitian terdiri dari pemangku kepentingan terkait yaitu Walikota, Kepala Bagian Pemerintahan, anggota legislatif (Dewan Perwakilan Rakyat Daerah), staf kelurahan, dan tokoh masyarakat. Tehnik analisis data dengan menggunakan model analisis interaktif. Berdasarkan hasil analisis dapat diambil kesimpulan. Pertama, faktor pendukung pemekaran wilayah di Kelurahan Semanggi Kota Surakarta, meliputi; a) aspek administrasi, terdiri dari: (1) faktor batas wilayah kelurahan yang valid; (2) faktor prasarana kelurahan yang memadai dan mendukung kesejahteraan masyarakat; (3) jumlah penduduk kelurahan yang besar (44.000 jiwa); (4) adanya usulan pemekaran wilayah dari masyarakat. b) Aspek politik, terdiri dari: (1) negosiasi Walikota ke Kementerian Dalam Negeri; (2) langkah Camat untuk mengumpulkan dukungan dari masyarakat; (3) upaya Lurah menjadi penghubung aspirasi melalui rapat-rapat dengan RT, RW dan tokoh masyarakat. Kedua, faktor penghambat pemekaran wilayah di Kelurahan Semanggi Kota Surakarta, yaitu: luas wilayah kelurahan tidak memenuhi kriteria pemekaran sesuai peraturan perundang-undangan. Implikasi penelitian adalah pemerintah daerah perlu memperhatikan aspek administrasi dan aspek politik dalam pengusulan kebijakan pemekaran kelurahan.

Kata Kunci: Perumusan Kebijakan, Pemekaran Kelurahan, Aspek Administrasi, Aspek Politik

\section{Abstract}

This study aims to analyze the factors that influence the expansion of urban areas in Semanggi Village, Surakarta City. This research uses descriptive qualitative research with a field study approach. Data were collected through observation, documentation, and interviews with local stakeholders related to the formulation of village expansion policies. Research informants consisted of relevant stakeholders, namely the Mayor, Head of Government Section, members of the legislature (Regional People's Representative Council), sub-district staff, and community leaders. Data analysis techniques using interactive analysis models. Based on the results of the analysis, conclusions can be drawn. First, the supporting factors for regional expansion in Semanggi Village, Surakarta City, include; a) administrative aspects, consisting of: (1) valid kelurahan area boundary factors; (2) adequate urban village infrastructure factors that support the welfare of the community; (3) large urban village population (44,000 people); (4) there is a proposal for regional expansion from the community. b) Political aspects, consisting of: (1) negotiation of the Mayor to the Ministry of Home Affairs; (2) the steps of the Camat to gather support from the community; (3) Lurah's efforts to become a liaison for aspirations through meetings with RT, RW and community leaders. Second, the inhibiting factor for regional expansion in Semanggi Village, Surakarta City, namely: the area of the village does not meet the criteria for expansion according to the legislation. The implication of the research is that local governments need to pay attention to administrative and political aspects in proposing policies for kelurahan expansion.

\section{Keywords: Policy Formulation, Kelurahan Expansion, Administrative Aspect, Political Aspect}

How to Cite: Tiemority, D.R. \& Suharto, D.G. (2021). Aspek Administrasi dan Politik dalam Kebijakan Pemekaran Kelurahan di Kota Surakarta. PUBLIKAUMA: Jurnal Ilmu Administrasi Publik UMA, 9 (1): 47-56 


\section{PENDAHULUAN}

Pemekaran daerah atau wilayah menjadi tren di Indonesia sejak pasca era reformasi. Usulan pemekaran diajukan daerah dengan berbagai pertimbangan positifnya. Pemekaran daerah secara filosofis dimaksudkan untuk meningkatkan kesejahteraan masyarakat karena akan mempersingkat rentang kendali antara pemerintah sebagai penyedia layanan publik dan masyarakat (Yuwanto, 2015).

Pembentukan daerah dimaksudkan untuk meningkatkan pelayanan publik guna mempercepat terwujudnya kesejahteraan masyarakat, di samping sebagai sarana pendidikan politik lokal (Widjaja, 2005). Dengan alasan memanfaatkan peluang untuk mengelola daerah secara mandiri, telah memicu terjadinya pemekaran di berbagai wilayah di Indonesia (Rifdan, 2012).

Kebijakan pemekaran wilayah pada beberapa waktu terakhir memunculkan pro dan kontra yang memperdebatkan manfaat dan kerugian dari dampak kebijakan pemekaran. Kebijakan pemekaran sekarang menjadi lebih diperketat. Beranjak dari hal tersebut, satu hal yang menarik dikaji adalah terkait penyusunan atau formulasi kebijakan pemekaran.

Proses penyusunan kebijakan merupakan satu rangkaian aktivitas yang tidak terpisahkan dari sebuah proses kebijakan, artinya suatu aktivitas yang berlasung secara simultan. Dalam proses penyusunan kebijakan terdapat proses tawar menawar (bargaining) yang terjadi antara aktor-aktor pembuat kebijakan dengan menggunakan kekuasaan dan kewenangan dilaksanakan bukan untuk menyinkronkan kepentingan rakyat, namun digunakan untuk meraih kepentingan (interest) dan kekuasaan (power) itu sendiri (Madani, 2011).

Dinamika formulasi kebijakan pemekaran bukan hanya dalam hal pemekaran di tingkat provinsi atau kabupaten/kota, kebijakan pemekaran tingkat kelurahan juga tidak kalah dinamis.

Kelurahan dibentuk di kawasan perkotaan dan atau di wilayah ibukota kabupaten/kota dan kecamatan (Peraturan Menteri Dalam Negeri Nomor 31 Tahun 2006 Tentang Pembentukan, Penghapusan, Dan Penggabungan Kelurahan, 2006). Pemekaran kelurahan merupakan pemecahan satu wilayah kelurahan menjadi dua atau lebih dengan pertimbangan karena keluasan wilayahnya, kondisi geografisnya, pertumbuhan jumlah penduduk, efektivitas dan efisiensi dalam pelayanan publik serta kondisi sosial politik yang ada (Sapi'i et al., 2013)

Kelurahan Semanggi memiliki cakupan wilayah yang luas dengan jumlah penduduk yang banyak (Peraturan Daerah Kota Surakarta Nomor 14 Tahun 2017 Tentang Pemekaran Kelurahan Semanggi Dan Kelurahan Kadipiro, 2017), sehingga menyebabkan pelayanan tidak optimal. Pada Tahun 2017 Kelurahan Semanggi Kota Surakarta memiliki luas $1,66 \mathrm{~km}^{2}$ yang terbagi menjadi $23 \mathrm{RW}$ dan $131 \mathrm{RT}$ dengan jumlah penduduk 34.770 jiwa dengan angka kepadatan 20.945 jiwa $\mathrm{km}^{2}$ (B. P. S. Surakarta, 2019). Mencermati data demografi yang berupa jumlah penduduk dalam satu kelurahan tersebut menyimpan potensi tidak optimalnya pelayanan pemerintah kelurahan kepada masyarakat disebabkan banyaknya jumlah penduduk yang harus dilayani. Namun kenyataan lain, data luas lahan yang dimiliki oleh Kelurahan Semanggi hanya 1,66 km², sedangkan dalam peraturan pemerintah untuk dapat dilakukannya pemekaran suatu wilayah minimal luas tanah $3 \mathrm{~km}^{2}$ (B. P. S. Surakarta, 2019).

Mengacu kepada Permendagri Nomor 31 tahun 2006 tentang Pembentukan, Penghapusan, dan Penggabungan Kelurahan yang mengatur batas minimal luasan satu wilayah kelurahan perkotaan, yakni 3 kilometer persegi dengan jumlah penduduk minimal 4.500 jiwa atau $900 \mathrm{KK}$, kemudian kelurahan tersebut dimekarkan (Peraturan Daerah Kota Surakarta Nomor 14 Tahun 2017 Tentang Pemekaran Kelurahan Semanggi Dan Kelurahan Kadipiro, 2017).

Menurut Peraturan Pemerintah Nomor 73 tahun 2005 tentang Kelurahan, pada Pasal 2 ayat (1) kelurahan dibentuk di wilayah kecamatan. Pasal (2) menjelaskan bahwa pembentukan kelurahan sebagaimana dimaksud pada ayat (1) dapat berupa penggabungan beberapa kelurahan atau bagian kelurahan yang bersandingan, atau pemekaran dari satu kelurahan menjadi dua 
kelurahan atau lebih. Syarat teknis dari pembentukan kelurahan sebagaimana yang dimaksud dalam Peraturan Pemerintah tahun 73 tahun 2005 Pasal 2 ayat (3) bahwa pembentukan kelurahan sekurang-kurangnya memenuhi syarat jumlah penduduk, luas wilayah, bagian wilayah kerja dan sarana dan prasarana pemerintahan (Peraturan Pemerintah Nomor 73 Tahun 2005 Tentang Kelurahan, 2005).

Wacana pemekaran Kelurahan Semanggi Kota Surakarta sebenarnya sudah lama digulirkan, yaitu sejak tahun 2007. Namun demikian, usulan tersebut baru terealisasi pada tahun 2017, dengan ditandai terbitnya Peraturan Daerah Kota Surakarta Nomor 14 tahun 2017 tentang Pemekaran Kelurahan Semanggi dan Kelurahan Kadipiro. Penolakan dalam proses penyusunan kebijakan pemekaran terjadi karena Kelurahan Semanggi belum bisa dikatakan layak untuk dimekarkan.

Tidak dapat dipungkiri bahwa keberhasilan pemekaran kelurahan tersebut tidak dapat dilepaskan dari dinamika antar aktor di dalam mempengaruhi dan memperjuangkan kebijakan tersebut. Ini karena setiap kebijakan yang dirumuskan tidak lepas dari kepentingan para aktor yang ingin mendapat keuntungan terhadap kebijakan yang dibuat. Keterlibatan para aktor ini dalam beberapa kebijakan terkadang menyebabkan munculnya dinamika dan konflik kebijakan karena adanya benturan kepentingan.

Proses bargaining dapat terjadi dalam tiga bentuk, yaitu negosiasi (negotiation), saling memberi dan menerima (take and give) dan kompromi (compromise). Sesungguhnya penjelasan bargaining berakar pada istilah bahwa jika terdapat dua atau lebih aktor atau kelompok aktor yang masing-masing memiliki kewenangan dan posisi tertentu tetapi dapat melakukan penyesuaian (sharing) yang diharapkan dapat terbangun dalam sistem pembahasannya (Madani, 2011). Dengan demikian negosiasi menjadi langkah awal untuk membentuk opini dan mengarahkan aktor untuk melakukan langkah negosiasi.

Negosiasi adalah sebuah proses yang didalamnya dua pihak atau lebih bertukar barang dan jasa dan berupaya menyepakati tingkat kerjasama tersebut bagi mereka
(Ulinuha, 2013). Aktor kebijakan yang seringkali terlibat dalam proses perundingan dan pengambilan kebijakan internal birokrasi dapat berupa mereka yang mempunyai kekuasaan tertentu (authoritative) dan mereka yang tergolong sebagai partisipan atau aktor tidak resmi (Madani, 2011). Struktur mempengaruhi agensi dalam dua arti, yaitu memampukan (enabling) dan menghambat (constraining) (Ashaf, 2017). Dalam kebijakan pemekaran kelurahan, eksistensi aktor diduga memiliki peran strategis. Dugaan tersebut didukung realitas bahwa meskipun pemekaran kelurahan di Kelurahan Semanggi Kota Surakarta tidak memenuhi syarat dalam hal luas wilayah, namun akhirnya pemekarannya dapat disetujui. Aspek politik yang berupa peran aktor diduga berperan penting di saat aspek administrasi (luas wilayah) tidak mendukung kebijakan pemekaran. Fenomena yang terjadi di lokasi penelitian mengarah pada adanya dinamika politik aktor dalam formulasi kebijakan. Fakta tersebut memperlihatkan aspek administrasi dan aspek politik dalam pemekaran kelurahan menarik untuk dikaji. Beranjak dari sisi menarik tersebut, penelitian ini bertujuan untuk menganalisis aspek administrasi dan aspek politik yang menjadi faktor pendukung dan penghambat pemekaran Kelurahan Semanggi Kota Surakarta.

\section{METODE PENELITIAN}

Jenis penelitian ini adalah deskriptif kualitatif, yang mendeskripsikan faktor pendukung dan penghambat kebijakan pemekaran Kelurahan Semanggi Kota Surakarta. Teknik pengumpulan data melalui wawancara, observasi, dan dokumentasi. Informan ditentukan dengan menggunakan tehnik Purposive dan Snowball Sampling. Berdasarkan tehnik tersebut diperoleh enam informan, yaitu Walikota Surakarta, Kabag dan Kasubag pada Bagian Pemerintahan Sekretariat Daerah, Komisi I DPRD Surakarta, staf Kelurahan Semanggi, serta tokoh masyarakat Surakarta. Observasi dilakukan terhadap situasi dan kondisi Kelurahan Semanggi Kota Surakarta. Dokumentasi berupa dokumen yang berkaitan dengan proses pemekaran Kelurahan Semanggi Kota Surakarta, seperti peraturan dan monograf. 
Triangulasi yang digunakan dalam penelitian ini adalah triangulasi sumber.

Tehnik analisis data dengan model analisis interaktif. Analisis data dilakukan secara interaktif dan terus menerus kepada informan hingga data yang diperoleh jenuh. Komponen dari teknik analisis data terdiri dari pengumpulan data, reduksi data, penyajian data, dan penarikan kesimpulan.

\section{HASIL DAN PEMBAHASAN}

Pemekaran wilayah membawa dampak positif bagi pelayanan publik. Karena adanya pemekaran, jarak tempuh masyarakat menjadi lebih dekat, pelayanan yang diberikan menjadi lebih efektif dan efisien (Nikasari, 2016). Pemekaran kelurahan pada hakekatnya untuk lebih mendekatkan jarak antara pemberi pelayanan publik (pemerintah) dengan pengguna pelayanan (masyarakat).

Salah satu faktor yang menjadi dasar adanya usulan kebijakan pemekaran di Kelurahan Semanggi Kota Surakarta adalah agar masyarakat Semanggi memperoleh pelayanan berkualitas yang diharapkan dapat mengatasi persoalan kemiskinan. Terkait kebijakan pemekaran, Walikota Surakarta menyatakan sebagai berikut.

"Indikator pemekaran itu apa tho, satu luas wilayah, kepadatan penduduk, penduduk miskin. Lantas dengan luas wilayah dan kepadatan penduduk serta penduduk miskinnya itu banyak sehingga perlu ada pemekaran" (Hasil Wawancara, 1 November 2020).

Kepala Bagian Pemerintahan Pemerintah Kota Surakarta mempertegas bahwa:

"Komitmen Walikota, untuk lebih memberikan pelayanan yang prima kepada masyarakat maka perlu ada pemekaran kelurahan" (Hasil Wawancara, 30 September 2020).
Demikian pula seperti yang tercantum dalam Permendagri Nomor 31 tahun 2006 tentang Pembentukan, Penghapusan, dan Penggabungan Kelurahan pasal 2, tujuan dari pembentukan kelurahan adalah untuk meningkatkan pelayanan masyarakat, melaksanakan fungsi pemerintahan, dan pemberdayaan masyarakat dalam rangka mempercepat terwujudnya kesejahteraan masyarakat (Peraturan Menteri Dalam Negeri Nomor 31 Tahun 2006 Tentang Pembentukan, Penghapusan, Dan Penggabungan Kelurahan, 2006).

Menurut Peraturan Pemerintah Nomor 73 tahun 2005 maupun Permendagri Nomor 31 tahun 2006, Pembentukan kelurahan dapat berupa penggabungan beberapa kelurahan atau bagian kelurahan yang bersandingan atau pemekaran dari satu kelurahan menjadi dua kelurahan atau lebih. Pembentukan kelurahan harus sekurang-kurangnya memenuhi syarat, yaitu jumlah penduduk, luas wilayah, bagian wilayah kerja, serta sarana dan prasarana pemerintahan.

Kelurahan Semanggi merupakan salah satu kelurahan di Kecamatan Pasar Kliwon Kota Surakarta. Kelurahan Semanggi yang semula hanya terdiri dari satu kelurahan, setelah dimekarkan menjadi dua kelurahan yang terdiri dari Kelurahan Semanggi dan Kelurahan Mojo. Jumlah penduduk di Kelurahan Semanggi sebelum dimekarkan sangat besar, lebih dari 34 ribu jiwa yang terdiri dari 23 RW dan 131 RT. Kepadatan penduduk yang tinggi mendorong perlunya pemekaran kelurahan. Pada tahun 2018, Kelurahan Semanggi berhasil dimekarkan menjadi dua kelurahan yaitu Semanggi dan Mojo. Setelah dimekarkan, Kelurahan Semanggi terdiri dari $15 \mathrm{RW}$ dengan jumlah KK 6.795, dan Kelurahan Mojo terdiri dari 8 RW dengan jumlah KK sebanyak 10.666 (B. P. S. Surakarta, 2019).

Usulan pemekaran wilayah Semanggi sudah dilakukan sejak tahun 2007. Setiap 
usulan yang diajukan oleh Pemerintah Kota Surakarta ditolak karena dianggap Kelurahan Semanggi belum layak diadakan pemekaran. Keberhasilan pemekaran dapat diwujudkan setelah melalui proses dinamis dan Panjang dengan berbagai faktor pendukung dan penghambat. Berikut ini disajikan faktor yang mempengaruhi penyusunan kebijakan pemekaran dikaji dari aspek administrasi dan aspek politik.

Aspek administrasi terdiri dari aspek fisikal dan non fisikal. Aspek fisikal terdiri dari faktor luas wilayah, batas wilayah dan prasarana kelurahan. Sedangkan aspek non fisikal terdiri dari jumlah penduduk, aspirasi masyarakat dan potensi ekonomi (Wardana, 2016). Aspek politik yang dimaksud adalah terkait interaksi dan negosiasi aktor dalam proses penyusunan kebijakan (Madani, 2011); (Giddens, 2010); (Lewicki et al., 2015); (Ulinuha, 2013); (Guswai, 2013).

\section{Aspek Administrasi}

a) Luas Wilayah

Luas wilayah menjadi salah satu persyaratan secara administratif dalam pengusulan kebijakan pemekaran di dalam suatu wilayah. Kepala sub Bidang Pengembangan Wilayah berpendapat bahwa faktor luas wilayah dipertimbangkan dalam rencana pemekaran kelurahan.

"Kita juga melihat kondisi geografisnya, luas lahannya apakah masih bisa dimekarkan apa tidak. Kalau lahannya sempit ya mau gimana lagi, tapi kalau lahannya luas bisa dibagi menjadi dua atau beberapa, itu juga menjadi pertimbangan" (Hasil Wawancara, 7 Oktober 2020).

Disebutkan dalam Permendagri Nomor 31 tahun 2006 Pasal 5 (2), ketentuan persyaratan luas wilayah pembentukan kelurahan yaitu: a. Jawa dan Bali paling sedikit $3 \mathrm{~km}^{2}$; b. Sumatera dan
Sulawesi paling sedikit $5 \mathrm{~km}^{2}$; dan c. Kalimantan, Nusa Tenggara, Maluku dan Papua paling sedikit $7 \mathrm{~km}^{2}$. Jadi, Kelurahan Semanggi yang berada di Pulau Jawa apabila luas wilayah kurang dari $3 \mathrm{~km}^{2}$, maka dapat dikatakan belum memenuhi syarat pemekaran. Luas wilayah menjadi faktor penghambat proses pemekaran kelurahan di Kelurahan Semanggi Kota Surakarta, karena luas Kelurahan Semanggi hanya $1,66 \mathrm{~km}^{2}$.

b)Batas Wilayah

Kondisi batas wilayah juga menjadi salah satu faktor yang berpengaruh terhadap kebijakan pemekaran kelurahan. Batas wilayah merupakan tanda pemisah antara wilayah yang bersebelahan baik yang berupa batas alam maupun batas buatan. Batas wilayah kelurahan dapat dinyatakan dalam bentuk peta kelurahan. Batas wilayah akan menunjukkan keberadaan wilayah/daerah kerja kelurahan. Permendagri Nomor 31 tahun 2006 Pasal 5 ayat (3) menyebutkan yang dimaksud bagian wilayah kerja adalah wilayah yang dapat dijangkau dalam meningkatkan pelayanan dan pembinaan masyarakat. Berdasar penelitian, data koordinat Kelurahan Semanggi valid dan dapat digunakan dalam pembuatan peta dengan baik. Kelurahan Semanggi memiliki batas wilayah sebagai berikut: Utara (Kelurahan Sangkrah, dan Kelurahan Pasar Kliwon), Selatan (Kelurahan Mojo), Barat (Kelurahan Pasar Kliwon) dan Timur (Kabupaten Sukoharjo). Dengan demikian, faktor batas wilayah kelurahan memiliki kejelasan sehingga mendukung pemekaran Kelurahan Semanggi tahun 2018.

c) Prasarana Kelurahan

Dinyatakan dalam Permendagri Nomor 31 tahun 2006 Pasal 5 (4), sarana dan prasarana pemerintahan sebagai syarat pembentukan kelurahan yaitu: memiliki kantor pemerintahan, memiliki jaringan perhubungan yang lancar, sarana komunikasi yang memadai, dan fasilitas umum yang memadai. 
Berdasarkan hasil observasi, sarana dan prasarana yang disebutkan dalam peraturan secara keseluruhan telah tersedia dengan baik. Prasarana tersebut diantaranya fasilitas pendidikan (12 SD/MI, 2 SMP/MTS, dan 2 SMA/MA) dan fasilitas kesehatan (1 balai pengobatan, 1 Puskesmas pembantu, dan 3 Apotik). Kota Surakarta yang berada pada persimpangan antar provinsi di Pulau Jawa memiliki dukungan sarana dan prasarana yang memadai, sehingga dapat disimpulkan keberadaan sarana dan prasarana di Kelurahan Semanggi Kota Surakarta menjadi faktor pendukung dalam pemekaran Kelurahan Semanggi.

Potensi wilayah merupakan cerminan tersedianya sumber daya yang dapat dimanfaatkan dan dapat memberikan sumbangan terhadap penerimaan daerah serta kesejahteraan masyarakat yang dapat diukur dari tersedianya sarana dan prasarana pendidikan dan kesehatan (Labolo, 2015).

d) Jumlah Penduduk

Kelurahan Semanggi terdiri dari 11 dusun yaitu Jayengan, Gandekan, Keparen, Surobawon, Kartodipuran, Borotodipuaran, Nyutran, Notokusuman, Macanan, Suroloyan dan Kali Larangan. Di Kelurahan Semanggi Kota Surakarta terdapat jumlah penduduk secara keseluruhan sebanyak 34.770 jiwa.

Jumlah penduduk Kelurahan Semanggi tersebut jauh melampaui batas minimal persyaratan jumlah penduduk dalam Permendagri Nomor 31 tahun 2006. Pasal 5 (1) Permendagri Nomor 31 tahun 2006 menyebutkan jumlah penduduk sebagai syarat pembentukan kelurahan paling sedikit adalah 4.500 jiwa atau 900 KK (wilayah Jawa dan Bali), 2.000 jiwa atau $400 \mathrm{KK}$ (wilayah Sumatera dan Sulawesi), dan 900 jiwa atau $180 \mathrm{KK}$ (wilayah Kalimantan, NTB, NTT, Maluku, Papua).

Setelah pemekaran Kelurahan Semanggi menjadi Kelurahan Semanggi

dan Kelurahan Mojo, maka komposisi jumlah penduduk masing-masing kelurahan hasil pemekaran menjadi 22.227 jiwa (penduduk Kelurahan Semanggi) dan 12.543 jiwa (penduduk Kelurahan Mojo) (Peraturan Daerah Kota Surakarta Nomor 14 Tahun 2017 Tentang Pemekaran Kelurahan Semanggi Dan Kelurahan Kadipiro, 2017).

Dari eksistensi jumlah penduduk kelurahan maka dapat ditarik benang merah bahwa faktor jumlah penduduk merupakan faktor yang mendukung pemekaran Kelurahan Semanggi Kota Surakarta pada tahun 2018. Bahkan, tingkat kepadatan yang tinggi (20.945 jiwa/ $\mathrm{km}^{2}$ J menjadi pendorong urgensi pemekaran kelurahan.

\section{Aspirasi Masyarakat}

Salah satu yang mendukung pemekaran di Kelurahan Semanggi Kota Surakarta adalah terkait adanya aspirasi masyarakat. Menurut informan dari kelurahan, usulan pemekaran juga berasal dari masyarakat.

"Usulan pemekaran memang bisa jadi berawal dari usulan masyarakat" (Hasil Wawancara dengan Sekretaris Kelurahan, 29 Mei 2020).

Lebih lanjut Kepala Bagian Pemerintahan menyatakan sebagai berikut.

"Masyarakat merasa kalau kelurahan ini melayani 30.000 orang ini tentunya tidak maksimal" (Hasil Wawancara, 30 September 2020).

Masyarakat menilai Kelurahan
Semanggi sudah padat penduduk,
pelayanan publik pemerintahan
terhambat, sehingga untuk peningkatan
mutu pelayanan yang terbaik adalah
melalui pemekaran kelurahan. Sebelum
pemekaran, petugas Kelurahan Semanggi
harus melayani lebih dari 34 ribu
penduduk. Masyarakat mengajukan
permohonan untuk dilakukan pemekaran
dengan pertimbangan penyelenggaraan


pelayanan dari kelurahan kepada masyarakat semakin baik, dan di sisi lain beban kerja kelurahan dalam pelayanan kepada masyarakat tidak terlalu berat karena harus melayani jumlah penduduk yang besar.

Usulan atau aspirasi masyarakat mengenai pemekaran Kelurahan Semanggi disampaikan oleh masyarakat dalam forum pertemuan Musyawarah Perencanaan Pembangunan (Musrenbang). Adanya usulan pemekaran diikuti dengan proses negosiasi antar aktor di kelurahan dan pemerintah kota.

Hal ini merupakan salah satu bentuk proses bargaining, yaitu bahwa negosiasi menjadi langkah awal untuk membentuk opini dan mengarahkan aktor untuk melakukan langkah negosiasi (Anderson, 1984). Setelah proses negosiasi antar aktor terjadi dalam posisi yang berbeda diantara aktor, maka prinsip saling memberikan dan menerima kemudian mewarnai proses pengambilan kebijakan yang di bahas dalam forum aktor yang terlibat.

\section{Potensi Ekonomi}

Secara umum, Kota Surakarta atau Kota Solo merupakan kota dagang dan industri yang mempunyai potensi ekonomi tinggi. Posisi Kelurahan Semanggi yang berada di Kecamatan Pasar Kliwon cukup strategis. Jarak Kelurahan Semanggi ke pusat pemerintahan kecamatan $\pm 900 \mathrm{~m}$, sedangkan jarak Kelurahan Semanggi ke pusat pemerintahan kota $\pm 3 \mathrm{~km}$.

Berdasarkan data statistik daerah, di Kelurahan Semanggi terdapat bermacam industri skala kecil, sedang dan besar, serta fasilitas perdagangan yang relatif lengkap. Potensi ekonomi yang ada dan berkembang di Kelurahan Semanggi dapat mendukung adanya kebijakan pemekaran kelurahan.

Data rinci tentang jumlah industri dan fasilitas perdagangan yang terdapat di Kelurahan Semanggi dapat dilihat dalam Tabel 1 berikut ini:
Tabel 1. Jumlah Industri dan Fasilitas Perdagangan di Kelurahan Semanggi

\begin{tabular}{lll}
\hline Kategori & \multicolumn{1}{c}{ Jenis } & Jumlah \\
\hline Industri & $\begin{array}{l}\text { Industri } \\
\text { besar/Sedang }\end{array}$ & 12 \\
& Kecil & 45 \\
& Rumah Tangga & 57 \\
Fasilitas & Pasar Tradisional & 4 \\
Perdagangan & Super Market & 2 \\
& Toko/Kios/Warung & 455 \\
& Rumah Makan & 286 \\
\hline
\end{tabular}

Sumber: (B. P. S. Surakarta, 2019)

\section{Aspek Politik}

Usulan pemekaran di Kelurahan Semanggi Kota Surakarta sudah lama diajukan, tetapi proses yang dilalui tidak mudah akibat kendala kurangnya persyaratan administratif. Persyaratan administratif tersebut terutama syarat luas wilayah minimal. Satu aspek penting yang berkontribusi dalam proses perumusan kebijakan pemekaran Kelurahan Semanggi adalah keterlibatan aktor-aktor kebijakan dari daerah dalam proses lobi/negosiasi dan agregasi kepentingan, termasuk melalui proses audiensi dan presentasi di Kementerian Dalam Negeri.

Aktor politik dalam kebijakan mempunyai pengaruh dalam suatu kelompok pemerintahan. Aktor politik dalam suatu pemerintahan memiliki kewenangan hukum yang diberikan oleh undang-undang yang secara alami memberikan pengaruh besar dalam pembentukan agenda kebijakan (Liu et al., 2010). Aktor-aktor dalam proses pembuatan kebijakan publik terdiri dari dua kelompok yaitu, aktor resmi seperti agen pemerintah (birokrat), presiden (eksekutif), DPR (legislatif) dan lembaga peradilan (yudikatif). Sedangkan aktor tidak resmi meliputi kelompok kepentingan seperti, partai politik dan warga negara di negara yang bersangkutan (Dewi, 2017).

Untuk memperjelas peran aktor yang ikut terlibat dalam kebijakan pemekaran di Kelurahan Semanggi Kota Surakarta dapat dijelaskan sebagai berikut:

a) Walikota Surakarta

Walikota dituntut untuk selalu berperan aktif menyelesaikan permasalahan di wilayahnya. Termasuk dalam hal ini adalah kepentingan yang diusung Walikota dalam memperjuangkan terbitnya kebijakan pemekaran Kelurahan Semanggi. Walikota 
Surakarta sebagai salah satu pihak yang melakukan pendekatan-pendekatan kepada Kementerian Dalam Negeri dalam pengajuan usulan pemekaran kelurahan.

Berkaitan dengan upaya Walikota dalam pemekaran Kelurahan Semanggi, Walikota Surakarta menyatakan bahwa, kalau Pemerintah Kota Surakarta mengikuti Peraturan Menteri dalam Negeri, maka akan terbentur aturan batas minimal luas wilayah sehingga tidak akan bisa dimekarkan. Oleh karena itu, Pemerintah Kota melalui Walikota melakukan pendekatan kepada Kementerian Dalam Negeri dengan memberikan argumentasi yang mendasar dan masuk akal, yaitu pemekaran diperlukan dalam rangka penanganan kemiskinan, sementara jika penduduknya sangat padat maka sasaran, proses pendataan dan proses penganggaran tidak akan fokus.

Sebagaimana dinyatakan Walikota berikut ini.

"Kami memberikan argumentasi ke sana (Kemendagri), kita datang sendiri ke sana. Kalau kita mengikuti Permendagri dengan luas itu tidak akan bisa dimekarkan, namun kita berargumen dalam rangka melakukan bagaimana upaya mengentaskan kemiskinan, sehingga argumentasinya mendasar dan masuk akal, makanya diizinkan untuk melakukan pemekaran kelurahan" (Hasil Wawancara, 1 November 2020).

Peran Walikota tersebut dalam kerangka tugas dan tanggungjawabnya sebagai Kepala Daerah untuk mendukung aspirasi masyarakat. Dalam proses bargaining dapat terjadi dalam tiga bentuk, yaitu: negosiasi (negotiation), saling memberi dan menerima (take and give) dan kompromi (compromise) (Anderson, 1984).. Peran Walikota Surakarta dalam kebijakan pemekaran Kelurahan Semanggi merupakan bentuk dari proses bargaining yang dominan berupa negoisasi (negotiation), yaitu melakukan negosiasi dengan Kemendagri agar usulan pemekaran Kelurahan Semanggi Kota Surakarta dapat diterima.

b) Kepala Bagian Pemerintahan

Kepala Bagian Pemerintahan mempunyai tugas antara lain: penyiapan bahan pengkoordinasian perumusan kebijakan daerah, penyiapan bahan pengkoordinasian pelaksanaan tugas perangkat daerah, penyiapan bahan pemantauan dan evaluasi pelaksanaan kebijakan daerah, dan penyiapan bahan pelaksanaan pembinaan administrasi di bidang administrasi pemerintahan, administrasi kewilayahan dan kerja sama dan otonomi daerah. Terkait perannya dalam pemekaran kelurahan Kepala Bagian Pemerintahan berpendapat sebagai berikut.

"Kabag Umum ikut andil dalam pengumpulan berkas-berkas sebagai prasyarat pengajuan pemekaran yang disampaikan kepada Walikota dan selanjutnya diajukan ke Pusat." (Hasil Wawancara, 30 September 2020).

Kepala Bagian Pemerintahan dalam proses negosiasi usulan kebijakan pemekaran di Kelurahan Semanggi Kota Surakarta mendukung peran Walikota.

c) Camat

Keterlibatan Camat Pasar Kliwon dalam memberikan dukungan pada proses pemekaran Kelurahan Semanggi Kota Surakarta ditopang oleh posisi strategis sebagai pimpinan wilayah di kecamatan. Sedangkan menurut Kabag Pemerintahan menyatakan sebagai berikut.

"Tokoh di wilayah yang terlibat adalah Camat dan Lurah. Mereka termasuk yang getol sekali dalam pemekaran kelurahan." (Hasil Wawancara, 30 September 2020)

Argumentasi Camat berupa penjelasan rasionalisasi pentingya pemekaran Kelurahan Semanggi Kota Surakarta, seperti pelayanan yang prima dari petugas kepada masyarakat. Dukungan terhadap proses pemekaran juga melalui peran Camat dalam melengkapi beberapa persyaratan administrasi pemekaran, data, dan konsolidasi aparat kelurahan, tokoh masyarakat, dan stakeholder kecamatan lain.

Informasi yang faktual, akurat dan relevan dapat memberikan masukan yang sangat berarti bagi para pengambil kebijakan dalam rangka penyelesaian perumusan (Dewi, 2017).

Dukungan yang diberikan Camat sebagai pimpinan wilayah kecamatan sangat berarti 
dalam konteks memperbesar kekuatan politik. Pimpinan di wilayah memiliki akses politik dan sumber daya untuk melakukan komunikasi politik dari masyarakat bawah ke Pemerintah Kota Surakarta, DPRD Surakarta dan kekuatan politik lainnya sehingga kepentingan terkait pemekaran bisa tercapai.

d) Lurah

Posisi Lurah sebagai pimpinan pemerintahan paling bawah memiliki peran dalam menginisiasi usulan pemekaran dari akar rumput. Peran Lurah dimulai dari menginisiasi dan menjembatani aspirasi masyarakat ke tingkat pemerintahan lebih tinggi, yaitu Kecamatan. Sebagai aktor lokal yang langsung berinteraksi dengan masyarakat, tugas seorang Lurah menjadi penghubung aspirasi masyarakat, sekaligus pendukung eksekutif dalam melengkapi beberapa berkas administrasi pemekaran. Intensitas komunikasi yang tinggi dengan stakeholder Kelurahan melalui rapat dan koordinasi dengan RT, RW, BPD dan tokoh masyarakat berhasil membangun sinergi dan kesadaran bersama bahwa pemekaran Kelurahan Semanggi Kota Surakarta adalah dalam rangka mewujudkan kesejahteraan dan pelayanan masyarakat yang lebih baik.

Hal tersebut menunjukkan bahwa para aktor yang berperan dalam kebijakan pemekaran di Kelurahan Semanggi Kota Surakarta dalam menjalankan perannya telah berhasil meyakinkan stakeholder, terkait argumentasi dilakukannya pemekaran, termasuk mempersuasi kepada masyarakat setempat sehingga masyarakat ikut mendukung adanya kebijakan pemekaran Kelurahan Semanggi Kota Surakarta.

Berdasarkan uraian di atas, dapat diambil kesimpulan bahwa aspek administrasi yang terdiri dari batas wilayah, prasarana kelurahan, jumlah penduduk dan aspirasi masyarakat mendukung untuk dilakukannya pemekaran di Kelurahan Semanggi Kota Surakarta, sedangkan luas wilayah menjadi penghambat. Aspek politik, khususnya dalam hal lobi/negosiasi dengan pemerintah pusat dan agregasi kepentingan di level bawah, dalam pemekaran Kelurahan Semanggi Kota Surakarta menjadi faktor pendukung.

Proses pemekaran kelurahan di Kota Surakarta tersebut terbilang tidak mudah dilakukan, karena terdapat syarat administrasi yang tidak bisa terpenuhi. Kepala Bagian Pemerintahan menyatakan sebagai berikut.

"Prosesnya susah karena ada aturan luas yang tidak memenuhi" (Hasil Wawancara, 30 September 2020).

Keberhasilan proses pemekaran kelurahan yang ditandai oleh adanya ijin dari Kementerian Dalam Negeri dipengaruhi oleh peran aktor (terutama Walikota) dalam melakukan negosiasi. Eksistensi keberadaan aktor itu sejalan dengan hasil penelitian yang dilakukan oleh (Liu et al., 2010) yang menunjukkan bahwa aktor politik dalam kebijakan mempunyai pengaruh dalam suatu kelompok pemerintahan.

Peran aktor dalam formulasi kebijakan yang berupa negosiasi tersebut mencerminkan pandangan dari (Anderson, 1984) bahwa salah satu bentuk dari proses bargaining adalah adanya negosiasi (negotitation).

\section{SIMPULAN}

Kebijakan pemekaran Kelurahan Semanggi Kota Surakarta yang diajukan sejak tahun 2007 baru terealisasi pada tahun 2017. Proses formulasi kebijakan pemekaran tersebut dipengaruhi oleh aspek administrasi dan politik.

Aspek administrasi meliputi faktor luas wilayah, batas wilayah, prasarana kelurahan, jumlah penduduk, aspirasi masyarakat, dan potensi ekonomi. Faktor eksistensi luas wilayah kelurahan menjadi penghambat pemekaran Kelurahan Semanggi Kota Surakarta karena luas wilayah yang terlalu sempit sehingga tidak memenuhi syarat minimal pembentukan kelurahan sebagaimana diatur dalam Permendagri Nomor 31 tahun 2006.

Faktor yang mendukung proses pemekaran Kelurahan Semanggi meliputi faktor batas wilayah yang valid dan jelas sehingga dapat menunjukkan bagian wilayah kerja kelurahan dengan baik; prasarana kelurahan sebagai syarat pembentukan kelurahan yang memadai; jumlah penduduk besar yang jauh melebihi persyaratan minimal; adanya aspirasi masyarakat yang menginginkan peningkatan mutu pelayanan, khususnya pelayanan pemerintah kelurahan 
yang dinilai memiliki beban berat dalam melayani lebih dari 34 ribu penduduk; dan potensi ekonomi yang dapat mendukung pemekaran kelurahan, terutama dari sektor industri dan perdagangan.

Aspek politik berupa peran dan adanya dukungan yang bersifat politik dari aktoraktor strategis di daerah dalam bentuk lobi/negosiasi dengan pemerintah pusat dan agregasi kepentingan di level bawah. Aktor tersebut terutama Walikota dengan didukung Kepala Bagian Pemerintahan, Camat, dan Lurah.

Implikasi penting dari penelitian ini adalah perlunya pemerintah daerah untuk memperhatikan aspek administrasi dan aspek politik dalam pengusulan kebijakan pemekaran kelurahan agar bisa berjalan lancar. Kedua aspek tersebut terbukti mempengaruhi formulasi kebijakan pemekaran, khususnya aspek politik yang berupa negosiasi dari aktor politik.

\section{DAFTAR PUSTAKA}

Anderson, J. E. (1984). Public Policy Making. Holt, Reinhart and Winston.

Ashaf, A. F. (2017). Pola Relasi Media, Negara, Dan Masyarakat: Teori Strukturasi Anthony Giddens Sebagai Alternatif. Sosiohumaniora, 8(2), 205-218.

Dewi, R. (2017). Studi Kasus Penolakan Publik Atas Kebijakan Publik. Publikauma: Jurnal Administrasi Publik Universitas Medan Area, 5(1),

6. https://doi.org/10.31289/publika.v5i1.1165

Giddens, A. (2010). Teori Strukturisasi: DasarDasar Pembentukan Struktur Sosial Masyarakat. Pustaka Pelajar.

Guswai, C. F. (2013). Negotiation for Retail Business. PT. Elex Media Komputindo.

Labolo, M. (2015). Laporan Akhir Penelitian Kajian Akademis Pembentukan, Penggabungan dan Penghapusan Kelurahan di Provinsi DKI Jakarta. IPDN.

Lewicki, R. J., Barry, B., \& Saunders, D. M. (2015). Negosiasi. Salemba Empat.

Liu, X., Lindquist, E., Vedlitz, A., \& Vincent, K. (2010). Understanding local policymaking: Policy elites' perceptions of local agenda setting and alternative policy selection. Policy Studies Journal, 38(1), 69-91. https://doi.org/10.1111/j.15410072.2009.00345.x
Madani, M. (2011). Dimensi Interaksi Aktor dalam Proses Perumusan Kebijakan Publik. Graha Ilmu.

Peraturan Menteri Dalam Negeri Nomor 31 tahun 2006 tentang Pembentukan, Penghapusan, dan Penggabungan Kelurahan, (2006).

Nikasari, R. (2016). Dampak Pemekaran Wilayah Kecamatan Terhadap Pelayanan Publik: Studi Kasus Pemekaran Kecamatan Kranggan Kota Mojokerto. Universitas Airlangga.

Peraturan Pemerintah Nomor 73 tahun 2005 tentang Kelurahan, (2005).

Rifdan. (2012). Implementasi Kebijakan Pemekaran Daerah dalam Mendukung Integrasi Nasional Di Kabupaten Luwu Timur. Jurnal Ilmiah Ilmu Administrasi Publik, 1(1), 23. https://doi.org/10.26858/jiap.v1i1.206

Sapi'i, I., Murdyastuti, A., \& Makmur, M. H. (2013). Dampak Pemekaran Desa Terhadap Pembangunan Infrastruktur Desa Pecahan, Studi Kasus Pemekaran Desa Bagorejo Kecamatan Gumukmas Kabupaten Jember. Artikel Ilmiah Hasil Penelitian Mahasiswa, 1(1), 1-7.

Surakarta, B. P. S. (2019). Surakarta dalam Angka Tahun 2018.

Peraturan Daerah Kota Surakarta Nomor 14 tahun 2017 tentang Pemekaran Kelurahan Semanggi dan Kelurahan Kadipiro, (2017).

Ulinuha, Z. (2013). Strategi Negosiasi Bisnis Jack Advertising dengan Klien (Studi pada Klien Jack Advertising: Sampoerna, LG, dan Primarasa Food). Universitas Brawijaya.

Wardana, J. R. (2016). Deskripsi Faktor-Faktor yang Mendukung Pemekaran Wilayah Pekon Tambahrejo Barat. Jurnal Penelitian Geografi, 4(1), 1-11.

Widjaja, H. (2005). Penyelenggaraan Otonomi di Indonesia dalam rangka Sosialisasi UU No. 32 tahun 2004 tentang Pemerintahan Daerah (1st ed.). RajaGrafindo Persada.

Yuwanto. (2015). Persepsi Elit Lokal Terhadap Wacana Pemekaran Daerah Di Kabupaten Cilacap. POLITIKA : Jurnal Ilmu Politik, 6(2), 53-62. https://doi.org/10.14710/politika.6.2.2015. 53-62 